OPTIMUM. ECONOMIC STUDIES NR 2 (92) 2018

\author{
Ewa ROSZKOWSKA, PhD, Professor of the University of Bialystok \\ Faculty of Economics and Management, University of Bialystok \\ e-mail: e.roszkowska@uwb.edu.pl \\ ORCID: 0000-0003-2236-3462
}

DOI: 10.15290/oes.2018.02.92.16

\title{
COMPREHENSIVE ANALYSIS OF THE PROCESS OF POPULATION AGEING IN POLAND IN THE YEARS 1950-2016*
}

\begin{abstract}
Summary
Aim - The main aim of the study is to determine the dynamics of the ageing process of the Polish population and to present a forecast of population ageing based on comprehensive analysis of the age structure of this population. The separated components of this structure are biological age groups: $0-14,15-64,65$ years and more. The time period of the research comprises the years 1950-2016, while the population forecast by age is presented for 2020 and 2050. The elaboration includes data from GUS.

Research methodology - In assessing the level of the ageing of Polish society there were used, among others, the old age index, old age coefficient, a measure of the similarity of structures, a measure of the structural change intensity, and the median age.

Score - In the years 1950-2016 in Poland there were observed changes in the age structure of the population in age groups: 0-14 years old, 15-64 years old, 65 years old and more, including a steady trend in the percentage of people in the age group 0-14 years old and a steady upward trend in the percentage of people aged 65 and over, a strong upward trend in the old age index, and a strong tendency of increase in the post-working age dependency ratio. The Central Statistical Office's (GUS) forecasts indicate that the population ageing measured by changes in the age structure of the population and the shifting of the median age which are taking place in Poland in a dynamic manner, will continue with increased intensity over the next decades.

Originality/value - The added value of the work is the use of the similarity of structures and the intensity of structure changes, which together with an approach based on classical indicators allowed for a comprehensive analysis of the age structure of the Polish population in dynamic terms, determining the quantitative nature of changes in the age structure over time, the direction of these changes and their intensity. It was also pointed out that in light of the ongoing demographic transformations, the concept of silver economy understood as an economic system aimed at using the potential of the elderly and taking into account their needs is becoming a priority.
\end{abstract}

Key words: population ageing, biological age groups, age factor, median age

JEL: J11, C40

* This work was supported by the Polish Ministry of Science and Higher Education under subsidy for maintaining the research potential of the Faculty of Economy and Management, University of Bialystok. 


\section{Introduction}

"The ageing of the population is a global and irreversible process that varies in particular regions. In general, one may assume that the higher the rate of socio-economic development of the country is, the higher is the advancement of the population ageing" [Abramowska-Kmon, 2011, p. 19]. The ageing of population denotes the increase of the percentage of elderly people simultaneously with a decrease in the number of people aged 0-14. Changes in the number and structure of population in terms of age comprise three factors: the number of births, the number of deaths, and the migration balance. The ageing process of Poland's population is the result of the low rate of birth, the prolonging of the average life duration as a consequence of the civilization progress and the improvement of the standard of living, and also as a result of the negative migration balance [Compre: Podstawowe informacje o rozwoju demograficznym Polski do 2014 roku; Stańczak, Szałtys, 2017].

The research concerning the phenomenon of the population ageing has both a spatial (regarding the specification of the advancement level of demographic old age in a certain area) and a temporal character (related to the dynamics of changes in the level of this phenomenon in a certain time period) [Kowaleski, 2006; Kowaleski, 2011; Kowaleski, Szukalski (ed.), 2004, 2006; Podogrodzka, 2014; Podogrodzka, 2016a; Podogrodzka, 2016b; Potrykowska, 2003; Wolańska, 2013]. The research is also connected with the conditions of the population's ageing process and its socio-economic consequences [e.g. Wasilewska-Ostrowska, 2013; Rączaszek, Koczur (ed.), 2014; Baranowska, 2013; Jurek, 2012].

Demographic changes have an impact on the state of the economy, pension system, the labor market, the functioning of enterprises, the market for goods, and consumer goods. The effect of the population's ageing process in a certain area may be an increased burden for the working-age population in the increasing number of population in the post-production age, changes in the structure of the population's sources of income, change in the structure of the labor force, increased expenditures on providing for the increasing number of the postproduction age group, families and households, increasing demand for services in the sphere of health protection and social aid, or changes in the consumption structure. In order to realize the new challenges facing state social policy in the sphere of a senior-centric economy, it is necessary to diagnose and monitor the scale of the phenomenon of population old age in Poland in a temporal and regional perspective.

In theoretical and methodological research concerning the population ageing process the basic issue is to specify the age limit enabling the isolation of elderly people, i.e. the specification of it in subject terms and the definition of population ageing. There is no clear limit from which the limit of demographic old age is settled. Its value may be subject to changes depending on the moment of starting the research or conducting comparative analyses - as the age limit 
there is usually taken from 60 to 70 years old. Most frequently the beginning of old age is denoted as 60 years old (WHO) or 65 years old (UN, Eurostat) or there is introduced a separate limit for demographic old age for men (65 years old) and women - 60 years old [http://www.stat.gov.pl/gus/definicje_PLK_HTML. $\mathrm{htm}$ ?id=POJ-1718.htm, date of entry: 10.01.2018]. Additionally, there is used a division of people aged more than 60 years old into younger (60-69 years old), older (70-79 years old) and very old people (80 years old and more). In accordance with the classical classification suggested by E. Rosset $(1959,1971)$ population is considered as young when the old age coefficient is lower than $8 \%$; it is in the transitional phase between the state of demographic young age and old age when the coefficient oscillates from 8 to $12 \%$; while it is considered as old when the coefficient is higher than $12 \%$. In accordance with the classical scale of the UN that is used for the measurement of the degree of advancement of population ageing, the population is considered as young when the coefficient of old age is lower than $4 \%$, while it is considered as mature when it oscillates at $4-7 \%$, and finally, it is considered as old when the coefficient is higher than $7 \%$. Owing to the prolonging of the average duration of human life the scale of old age is undergoing modifications. Thus, in accordance with the modified scale of the UN, population is considered as young when the percentage of persons aged 65 and over is lower than $4 \%$, when the coefficient oscillates from 4 to $7 \%$ - mature, from 7 to $14 \%$ - getting old, from 14 to $21 \%$ - old, while more than $21 \%$ - hyper old [Jurek, 2012, p. 8].

In the subject literature one may observe many measures and classifications of assessing the degree of advancement of the population ageing. The most frequently used measures are based on the age structure of population divided into biological age groups (0-14 years old, 15-64 years old, 65 years old and more) and productive age groups (0-14 years old, 15-59 years old, 60 years old and more). They demonstrate the relations between the number (or the percentage) of persons in certain age groups illustrating thus the degree of generation renewal. The classical measures of the advancement level of the ageing process of population include, among others, old-age rate, ageing index, total dependency ratio, youth dependency ratio, old-aged dependency ratio, potential support ratio, parent support ratio or the participation of the oldest persons (80 years old and more) in the population of people aged 65 and over (double ageing) [Clarke, 1965; Rosset, 1959; Rosset, 1967; Kowaleski, 2011].

In the research on the advancement level of demographic old age there are used also statistical measures such as age median [Kosiński, 1967; Sanderson, Scherbov, 2005; Abramowska-Kmon, 2011], deciles or quartiles [Kowaleski, 2011], Gini concentration index [d'Albis, Collard, 2013], synthetic age structure indicator [Kurek, 2004; Kurek, 2008], measure of decomposition assymetry [Cieślak, 2004]. Other measures include also the measure of relative old age gap [Kot, Kurkiewicz, 2004], the index of dissimilarity [Rowland, 1996], the structural similarity measure [Podogrodzka, 2014]. 
For the analysis of the dynamics of the ageing process of population there is used, among others, information on the relations between the mean values of the ageing indexes [Długosz, 1998], the quotient of the average annual increase of the elderly population and the overall average annual rate of population growth [Frątczak, 2002; Kondrat, 1972], the aggregate index of population structure calculated as the quotient of the actual and standard death rate in the analyzed community [Wieniecki, 1981].

The paper is focused on the analysis of the demographic situation of Poland in the aspect of the ageing of Poland's population in the dynamic perspective. The main aim of the elaboration is to specify the dynamics of the ageing process of Poland's population in the years 1950-2016 and to show what the ageing of Poland's population is projected to look like in the years 2020 and 2050 using selected statistical measures describing the population age structure.

The isolated components of this structure are biological age groups: 014 years old, 15-64 years old and 65 years old and over. The first activities undertaken for each of the aforementioned groups included a separate analysis and a complex assessment of the age structure in the dynamic perspective. The analysis of the age structure of Poland population in the dynamic perspective enabled the specification of the quantity character of these changes in a time perspective, their direction and intensity. In the assessment of the degree of advancement degree of the demographic old age of Poland's population on the basis of the age structure there was used, among others, the ageing index, the coefficient of demographic burden, the measure of structure similarity, the measure of changes in the intensity of structures, and the median. The final stage made comparison of the results of research obtained using various statistical measures for the evaluation of the ageing process of Poland's population.

The second chapter presents the description of the research methodology, whereas the subsequent three chapters present the research results. The elaborating conclusion presents an outline of the direction of further research.

\section{Research method}

The description of demographic ageing in Poland and the existing relations between generations was made by using the quantity relations between the socalled biological age groups of population (0-14 years old - children, 15-64 lat - adults, 65 years old and over - elderly). The structure of the phenomenon was defined as the structure of the participation of particular age groups: 0-14, 15-64, 65 years old and over, in the entire population.

As the basic measure of demographic old age, there was adopted the old age rate, i.e. the participation of persons aged 65 years old and over in the entire population (the UN measure) in period, i.e. 


$$
O A R_{t}=\frac{L_{t}(+65)}{L_{t}} \cdot 100(\%)
$$

formula (1)

where:

$L_{t}(+65)$ - the number of population aged 65 years old and over in $t$ period,

$L_{t} \quad-\quad$ the number of population in general in $t$ period,

$t \quad-$ the research period of time $t=1950, \ldots, 2016,2020,2050$.

Ageing index, $A I_{t}$ represents the relation between the oldest and the youngest age group (in this case $0-14$ and 65 years old and over) in $t$ period, i.e.

$$
A I_{t}=\frac{L_{t}(+65)}{L_{t}(0-14)} \cdot 100
$$

where:

$L_{t}(+65)$ - the number of population aged 65 years old and over in $t$ period,

$L_{t}(0-14)$ - the number of population aged $0-14$ years old in $t$ period,

$t \quad-$ research date.

Old age index presents the relation of "the generation of grandparents" (65 years old and over) to "the generation of grandchildren" (0-14 years old). The value of an index higher than 100 means the advantage of the population aged 65 years old and over in relation to the group of persons aged 0-14 years old.

Another measure is the total dependency ratio:

$$
T D R_{t}=\frac{L_{t}(0-14)+L_{t}(+65)}{L_{t}(15-64)} \cdot 100
$$

which is the sum of youth dependency ratio:

$$
Y D R_{t}=\frac{L_{t}(0-14)}{L_{t}(15-64)} \cdot 100
$$

and old-aged dependency ratio:

$$
O A D R_{t}=\frac{L_{t}(+65)}{L_{t}(15-64)} \cdot 100
$$

where:

$L_{t}(+65)$ - the number of population aged 65 years old and over in $t$ period, $L_{t}(0-14)$ - the number of population aged $0-14$ years old in $t$ period, $L_{t}(15-64)$ - the number of population aged 15-64 years old in $t$ period, $t \quad-$ research date.

The comparison of the age structure of population by biological age was made for the selected years 1950-2016 using the measure of the similarity of age structures and chain indexes of the intensification of structural changes in time ${ }^{1}$.

1 The review of most frequently used similarity measures including the analysis of their pros and cons may be found, among others, in the following publication: [Młodak, 2006, pp. 52-65]. 
For assessing the similarity of population age structures there was used a similarity measure of figure structures [Chomątowski, Sokołowski, 1978; Młodak, 2006]:

$$
P_{i j}=\sum_{k=1}^{m} \min \left(w_{i k}, w_{j k}\right)
$$

where

$i, j \quad-$ numbers of study periods,

$k-$ number of the structure component,

$w_{i k}, w_{j k} \quad$ - participation of the $k$-th component in the total structure, respectively in the periods $i, j$,

$m$ - the number of distinguished components of the structure.

This determined the relations: $0 \leqslant w_{i k} \leqslant 1$ and $\sum_{k=1}^{m} w_{i k}=1$. The measure of the structure similarity is within the range $[0 ; 1]$. In the case of completely different structures, the measure $P_{i j}=0$; when the structures are identical, $P_{i j}=1$.

The structure components in $i$ period create the column vector, the components of which include the shares of the $k$ structure component in the overall structure considered in $i$ period. As a measure of the intensity of structural changes in $i$ period in comparison with $j$ period, there is adopted the value of the function sinus angle that is formed by two column vectors describing the structure of the phenomemon in periods $i$ and $j$ respectively [e.g. Wasilewska, 2014]:

where

$$
S_{i / j}=\sin \alpha=\sqrt{1-\frac{\left(\sum_{k=1}^{m} w_{i k} w_{j k}\right)^{2}}{\sum_{k=1}^{m} w_{i k}^{2} \sum_{k=1}^{m} w_{j k}^{2}}}
$$

$i, j \quad-$ numbers of research dates,

$k-$ number of the structure component,

$w_{i k}, w_{j k} \quad$ - participation of $k$ element in the total structure respectively in period $i, j$

$m \quad-$ number of isolated structure elements.

The measure $S_{i / j}$ adopts values in the range $[0,1]$. If $\sin u s \alpha=0$ is the angle between vectors $\alpha=0^{\circ}$ it means the covering of both vectors and the identical appearance of structures. When the value of the function sinus $\alpha$ heads for unity, i.e. the angle between the structure vectors $90^{\circ}$, it means that these vectors represent structures that are becoming less similar. Therefore, a value of measure $S_{i / j}$ close to 0 indicates insignificant changes in the age structure in time (i.e. in periods $i$ and $j$ the structures are similar), whereas a value of measure close to unity - with considerable changes in the age structure between period $i$ and $j$ (the so-called structure in $i$ period substantially differs from the structure in period $j$ ). Chain indexes $S_{t / t-1}$ are used for comparing the age structure of the population in $t$ period with the structure in the previous period $(t-1)$. 
The analysis of changes in the structure of population age is composed of three stages:

1. specification of the direction and intensification of changes in the time perspective for particular age groups setting the structure, i.e. the following age groups: 0-14 years old, 15-64 years old and 65 years old and over;

2. specification of the direction and intensity of changes in the period of the entire structure of population age using the structure similarity measure and the angular measure of the intensity of structural changes;

3. specification of the dynamics of changes in the relations between the isolated age groups creating the age structure, using the ageing index, the total coefficient of demographic burden, pre-productive age dependency ratio, and post-productive age dependency ratio.

For the assessment of the advancement of changes in the ageing level of Poland's population there was used also the age median. If the median value increases, it means that a certain population gets older, whereas the decrease of the median value means that the population is getting younger. There were presented also values of the average life expectancy of women and men aged 60 and 75 , i.e. the index showing how many years on average these persons may continue to live [e.g. Holzer, 2003].

\section{Analysis of changes in the structure of biological age in the context of the ageing process of Poland's population}

Poland's population in the years 1950-2016, then forecast for the years 2020 and 2050, taking into consideration biological age groups and trend functions describing these changes with a determination coefficient, is presented in chart 1.

All the trend functions (chart 1) are characterized by a low value of the linear regression index: positive for the age group 15-64 years old (0.0007) and 65 years old and over (0.0022), whereas it is negative for the age group $0-14$ years old (-0.0029). The determination coefficient indicates very strong adjustment of the linear function in the case of the age group 0-14 years old (0.9306), strong - in the case of being 65 years old and more (0.7501), and weak - the age group 15-64 years old (0.189). In the years 1950-2016 in Poland there were transformations in the structure of population by age - there was a reduction in the population aged 0-14 and at the same time there was an increase in the population of elderly people (chart 1 ). The forecasts prepared by GUS anticipate considerable intensification of these unfavorable tendencies.

In Poland since the 1950s there has been recorded an increase in the participation of population aged 0-14 years old - from $29.5 \%$ in 1950 to $33.5 \%$ in 1960, while in 1976 it was $23.8 \%$. Another insignificant increase, the consequence of the post-war baby boom, lasted till 1986 when the participation 


\section{CHART 1}

\section{The structure of Poland's population in the years 1950-2016 including the forecast for the years 2020-2050}

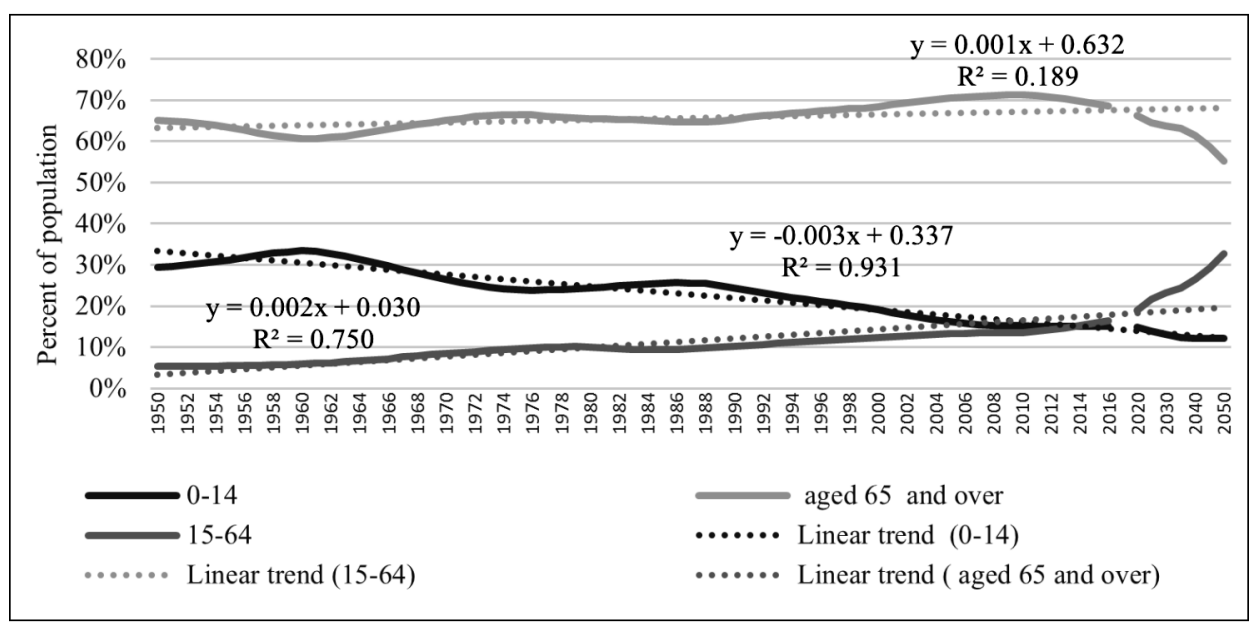

Source: [http://stat.gov.pl/obszary-tematyczne/ludnosc/prognoza-ludnosci/prognoza-ludnosci -na-lata-2014-2050-opracowana-2014-r-,1,5.html; http://stat.gov.pl/obszary-tematyczne/rocznikistatystyczne/roczniki-statystyczne/rocznik-demograficzny-2017,3,11.html; http://stat.gov.pl/ob szary-tematyczne/ludnosc/ludnosc/struktura-ludnosci,16,1.html, date of entry: 25.12.2017].

of persons aged 0-14 amounted to $25.7 \%$; then the percentage was subject to a constant decrease so that in 2016 it amounted to $15.0 \%$. The forecasts of GUS project a considerable reduction of population aged $0-14$ from $14.8 \%$ in 2020 to $12.1 \%$ in 2050 .

The percentage of population aged 15-64 was subject to a gradual decrease, i.e. from $65.2 \%$ in 1950 to $60.6 \%$ in 1961 (chart 1). Later on there was observed an insignificant increase from $61 \%$ in 1962 to $66.5 \%$ in 1974, a slight decrease to $64.7 \%$ in 1988 , a systematic increase to $71.3 \%$ in 2010 and a decrease to $68.6 \%$ in 2016. The forecasts from GUS indicate a decrease of the population of adults from $66.3 \%$ in 2020 to $55.2 \%$ in 2050 .

The percentage of population aged 65 and over increased regularly from $5.3 \%$ in 1950 to $10.2 \%$ in 1979 (chart 1). Later on there was observed an insignificant decrease to $9.4 \%$ in 1985 , while in 2016 it increased to the level of $16.4 \%$. The forecasts from GUS predict a considerable increase of population aged 65 and over $18.9 \%$ in 2020 to $32.7 \%$ in 2050 .

Changes in the age groups of Poland's population are presented in chart 2. The middle age group (15-64) had the highest and relatively stable participation in the age structure, whereas the shares of the remaining age groups showed the opposite tendency. In the years 1950-2016 the relative share of population aged 15-64 in the overall age structure increased from $65.2 \%$ in 1950 to $68.6 \%$ in 2016. 
CHART 2

The structure of Poland's population in accordance with biological age groups in the years 1950-2016 and forecast for the years 2020 and 2050

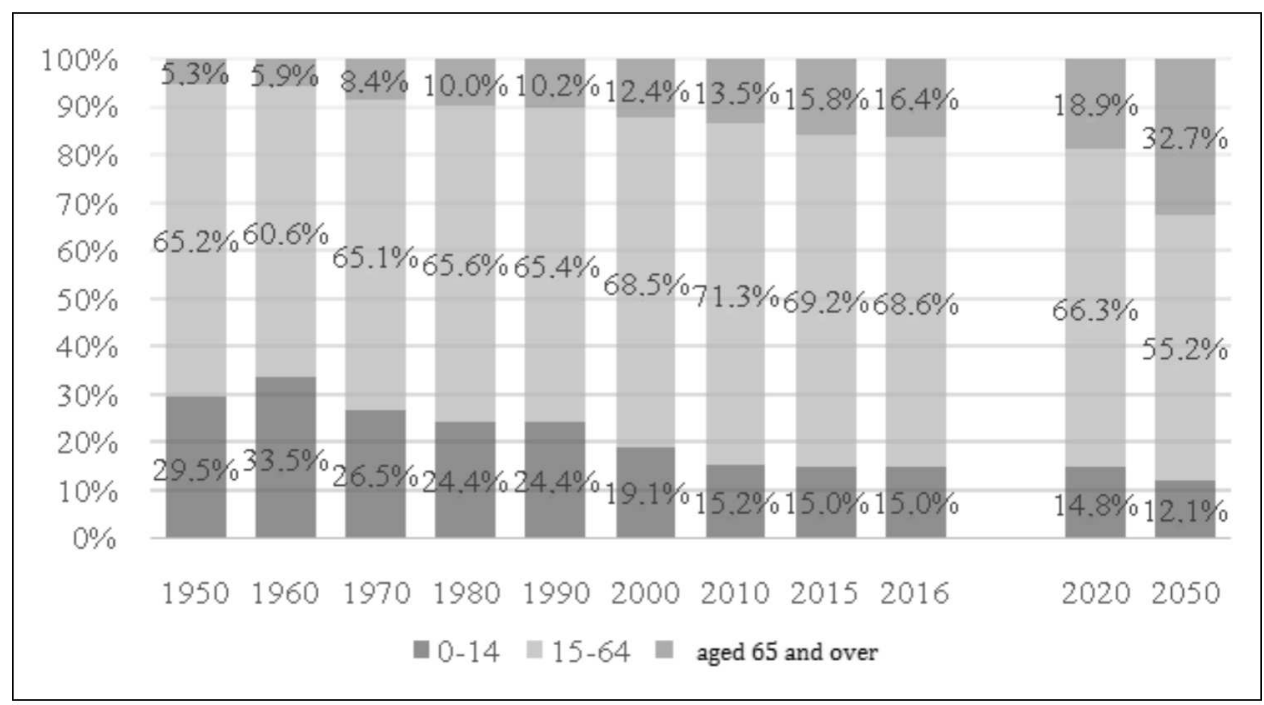

Source: see chart 1 .

The relative participation of population aged 0-14 years old in the entire population showed a downward trend, i.e. from $29.5 \%$ in 1950 to $15.0 \%$ in 2016, whereas for persons aged 65 years old and over in the entire population it indicates an upward trend, i.e. from 5.3\% in 1950 to $16.4 \%$ in 2016. In particular over the last dozen years there has been recorded a fast rate of increase of population aged 65 and over and also a stable increase of their participation in the entire population. These changes indicate the intensive ageing of Poland's population. It needs emphasizing that an essential factor in the ageing process in Poland that affected further relatively considerable changes in shaping the age structure was the demographic wave connected with the shift of subsequent groups in the age pyramid of age groups representing the baby boom and baby bust ${ }^{2}$.

2 The character of biological structure is determined by population growth, i.e. it is the difference between the number of live births and the number of deaths. The stages of Poland's demographic growth are as follows: 1) the 1950s - high demographic growth after World War II (with the culmination in 1956), the so-called compensation of war damages; 2) demographic decline in the 1960s (culmination in 1969) - the generation born during WWII entering reproductive age; 3) the baby boom of the 1970s (culmination in 1976) the so-called echo of the postwar surge; 4) demographic decline of the 1980s entering adult age by persons from the population decline period of the 1960s. Presently, there are low rates of population growth. "The low number of births has not guaranteed (for almost 25 years) simple generational replacement; since 1989 there has been observed a period 
In accordance with the modified classification of the UN, Poland's population in the years 1950-1965 may be considered as mature, and in the years 1966-2011 as an ageing population, whereas in the years 2012-2016 - as old. The forecasts from the Main Statistical Office (GUS) anticipate that from the year 2025 Poland's population will enter the stage termed as a hyper-old population.

In order to assess in temporal terms the degree to which the population's age structures underwent modifications, there was used a method of structure similarity which enabled the observation of characteristic changes in the structures of biological age in the dynamic perspective. The matrix of the value of the similarity measure of structures for selected years from 1950-2016 and for the years 2020 and 2050 is presented in table 1.

TABLE 1

Matrix of the value of similarity measure of Poland's population structures for selected years 1950-2016 and for the forecast years 2020 and 2050

\begin{tabular}{|l|c|c|c|c|c|c|c|c|c|c|c|}
\cline { 2 - 11 } \multicolumn{1}{c|}{} & 1950 & 1960 & 1970 & 1980 & 1990 & 2000 & 2010 & 2015 & 2016 & 2020 & 2050 \\
\hline 1950 & 1.000 & 0.954 & 0.969 & 0.949 & 0.949 & 0.896 & 0.857 & 0.855 & 0.855 & 0.853 & 0.726 \\
\hline 1960 & 0.954 & 1.000 & 0.930 & 0.909 & 0.909 & 0.856 & 0.817 & 0.815 & 0.815 & 0.813 & 0.732 \\
\hline 1970 & 0.969 & 0.930 & 1.000 & $0.979 *$ & 0.979 & 0.926 & 0.887 & 0.885 & 0.885 & 0.883 & 0.757 \\
\hline 1980 & 0.949 & 0.909 & 0.979 & 1.000 & 0.998 & 0.947 & 0.908 & 0.906 & 0.906 & 0.904 & 0.773 \\
\hline 1990 & 0.949 & 0.909 & 0.979 & 0.998 & 1.000 & 0.947 & 0.908 & 0.906 & 0.906 & 0.904 & 0.775 \\
\hline 2000 & 0.896 & 0.856 & 0.926 & 0.947 & 0.947 & 1.000 & 0.961 & 0.959 & 0.959 & 0.935 & 0.797 \\
\hline 2010 & 0.857 & 0.817 & 0.887 & 0.908 & 0.908 & 0.961 & 1.000 & 0.977 & 0.971 & 0.946 & 0.808 \\
\hline 2015 & 0.855 & 0.815 & 0.885 & 0.906 & 0.906 & 0.959 & 0.977 & 1.000 & 0.994 & 0.969 & 0.831 \\
\hline 2016 & 0.855 & 0.815 & 0.885 & 0.906 & 0.906 & 0.959 & 0.971 & 0.994 & 1.000 & 0.975 & 0.837 \\
\hline 2020 & 0.853 & 0.813 & 0.883 & 0.904 & 0.904 & 0.935 & 0.946 & 0.969 & 0.975 & 1.000 & 0.862 \\
\hline 2050 & 0.726 & 0.732 & 0.757 & 0.773 & 0.775 & 0.797 & 0.808 & 0.831 & 0.837 & 0.862 & 1.000 \\
\hline
\end{tabular}

* Grey colour was used for the highest values of similarity structure measure.

Source: see chart 1.

It may be observed that, with years passing by, the values of similarity measure decrease, which means a consistent trend from one period to another as regards the value of the similarity measure of age structures in the time perspective. The value of the similarity measure of age structures in 1950 and 2016 amounted to 0.855 . The largest similarity of age structures was observed for

of depression in terms of the number of births"..." Since the 1990s the value of general birth rate coefficient oscillates at less than 2, whereas the optimal value - specified as beneficial for stable demographic growth - to 2.10-2.15, i.e, when among 100 women aged 15-49 there are on average 210-215 children being born [Podstawowe informacje o rozwoju demograficznym Polski...]. 
the years: 1980 and 1990 (value $P_{1980,1990}=0,998$ ). Furthermore, considerable similarity of structures occurred in the years 2015 and $2016\left(P_{2015,2016}=0.994\right), 1990$ and $1970\left(P_{1970,1990}=0.979\right), 1970$ and $1980\left(P_{1970,1980}=0.979\right)$ (table 1$)$. GUS forecasts predict progressive changes in the similarity of age structures in Poland.

Chain measures of the intensification of changes in structure $S_{t / t-1}$ of population by biological age groups are presented in chart 3 . The observed changes in the values of intensity measures of structure $S_{t / t-1}$ from one year to another indicate the diversification of the phenomenon in the dynamic perspective. The smallest changes in the structure intensity were observed in the years 1975-1988 and 2007-2011, when the measure of the intensity of structural changes was lower than 0.0053. The largest changes in the structural intensity, in comparison with the previous year, were recorded in the years 1963-1968. While comparing the population structure in terms of the biological age groups in 2016 to the structure in 1950 one may observe that the intensity of structural changes in the years 1950-2016 amounted to $S_{2016 / 1950}=0.256$.

The conducted analysis of chain measures of the intensity of structural changes including the characteristic of the structure of Poland's population in accordance with biological age groups in the years 1950-2016 represented earlier (chart: 1,2) confirms the process of ageing of Poland's population that is taking place with varied intensity, but is systematically proceeding. In accordance with the forecasts of GUS the tendency in a long time perspective may contribute to the consolidation of regressive age structures. It needs emphasizing that the course of changes in the age structure is also related to the existence of high and low birth rates in the analyzed period (compare footnote 5).

CHART 3

The rate of changes of population structure by biological age groups in the years 1950-2016

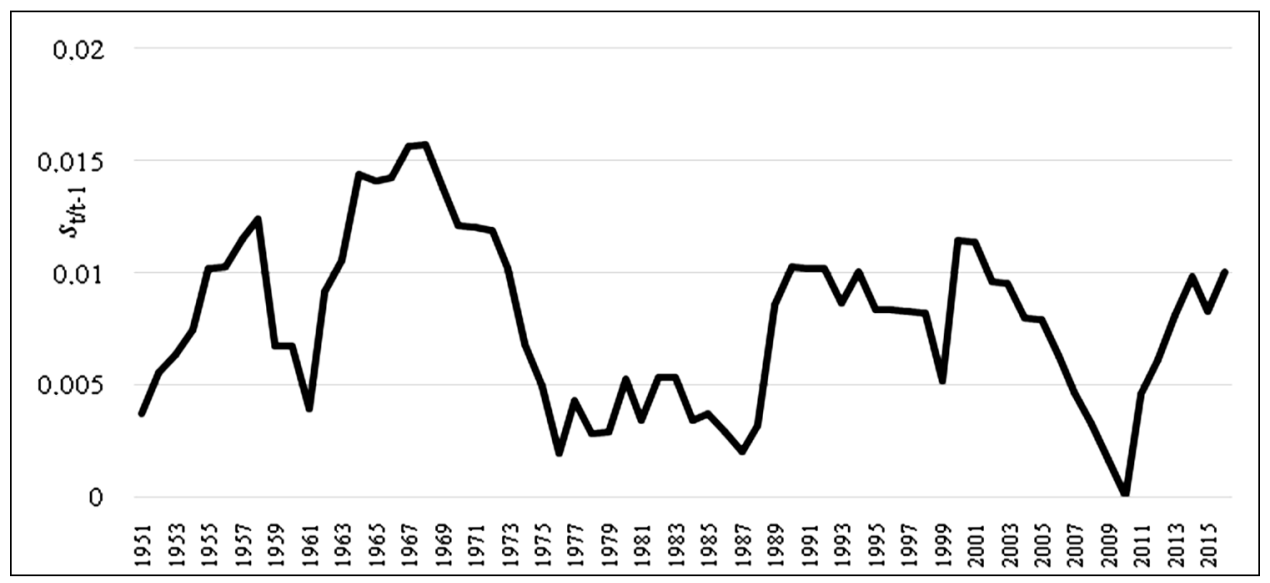

Source: see chart 1 . 
Summing up the results obtained in this part of the elaboration, one may assume that in the years 1950-2016 the changes in the structure of population age concerned above all the groups of children and teenagers (0-14 years old) and the group of elderly people (65 years old and more). The participation of children aged 0-14 in the entire population changed considerably. It decreased almost two times from $29.5 \%$ in 1950 to $15.0 \%$ in 2016 . In the same time, on the other hand, the participation of population aged 65 and over increased almost three times from $5.3 \%$ in 1950 to $16.4 \%$ in 2016. The participation of population aged 15-64 remained at almost the same level. The increase in the participation of elderly people is the consequence of prolonged average life expectancy and it is termed as "the ageing at the top of the population's age pyramid". On the other hand, the persisting low fertility rates in the analyzed period also contributed to the ageing of the society, whereas the lower rate of births led to decreasing the number of young people in the entire population. The process is termed as "the ageing at the base of the population's age pyramid".

\section{Evaluation of the ageing process of Poland's population using measures based on biological age groups}

A comprehensive analysis of the demographic situation requires taking into consideration also the relation between participation in particular age groups: the population of children and teenagers, adult people, and elderly people. The ageing index and ageing indicators offer such a possibility.

The index of demographic old age enables the evaluation of what is the old-age dependency ratio. The relations between the groups of children and grandparents reflect the shaping of the birth rate and fertility in the population. Demographic old age in a population occurs when the demographic ageing index is higher than 100, i.e. the age group 0-14 years old is less numerous than the population group aged 65 years old and over [Kurkiewicz, 2010, p. 129]. Chart 4 presents the ageing index in the years 1950-2016, the forecast for the years 2020-2050 taking into consideration age groups and the trend function describing these changes together with the determination coefficient.

The function of the linear trend (chart 4 ) is characterized by the positive value of the ratio (2.0275), whereas the determination coefficient (0.682) indicates moderate adjustment of the model to the data. In the years 1950-1979 there was observed an increase of the ageing index from 17.97 in 1950 to 42.32 in 1979, and in 1985 there was observed a slight decrease to 36.72. From the year 1986 there was a systematic increase of this index - to 109.33 in 2016. In 2012 the population of "grandparents" became more numerous than the population of children. In the year 1950 the ageing index amounted to 17.97, whereas in 2016 as much as 109.33. It means that per 100 children aged $0-14$ and over in 1950 there were approx. 18 senior persons, whereas in 2016 there were already more than 109 . 
CHART 4

Ageing index in the years 1950-2016 in Poland and forecast for the years 2020-2050

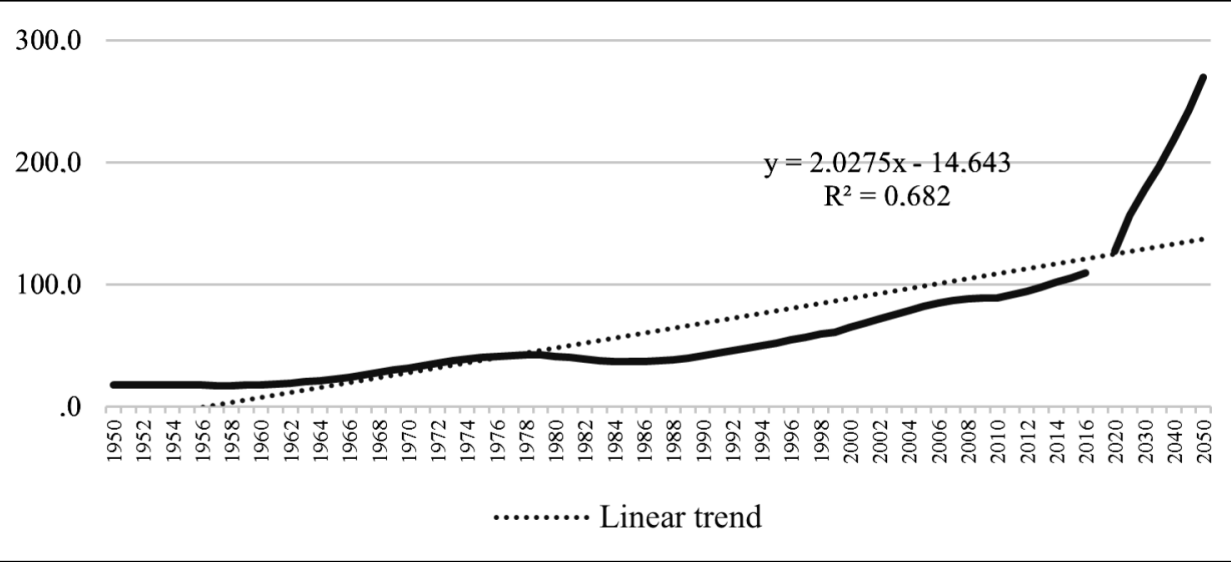

Source: see chart 1 .

The forecasts from GUS anticipate that in 2020 per one person there will be 1.23 grandparents, whereas in 2050 there will be already 2.69 grandparents. It is predicted that the value of the old age ratio will increase owing to the decreasing number of children (0-14 years old) resulting from the gradually decreasing number of people aged 65 years old and over.

The prediction of the number of people of a productive age, non-productive age or post-productive age has considerable importance for planning the country's economic policy. The knowledge may be useful for shaping the policy of granting pensions and disability benefits, labor market policy, or social policy. The ageing process of the population may not be considered only with regard to the elderly population/pop. in older age. The links between the three groups of population by age groups, i.e. between the population of a pre-productive age, of a productive age and of a post-productive age are illustrated by the total dependency ratio. The ratio shows how many people of a non-productive age live per 100 persons of a productive age.

In the case of both the old-age dependency ratio and the total dependency ratio there are observed similar periods of increase and decrease. Old-age dependency ratio indicates a general upward trend. In 1950 the ratio amounted to 0.081 , whereas in 2016 it amounted to 0.239. It means that in 1950 there were 81 persons, while in 2016 as many as 239 persons of a post-productive age per 1000 persons of a productive age. It is predicted that as a result of the reallocation of population among age groups the old age dependency ratio is likely to increase almost 2.5 times from 0.239 in 2016 to 0.592 in 2050 (chart 5). 
CHART 5

\section{Poland's population in the years 1950-2016 and forecast for the years 2020-2050}

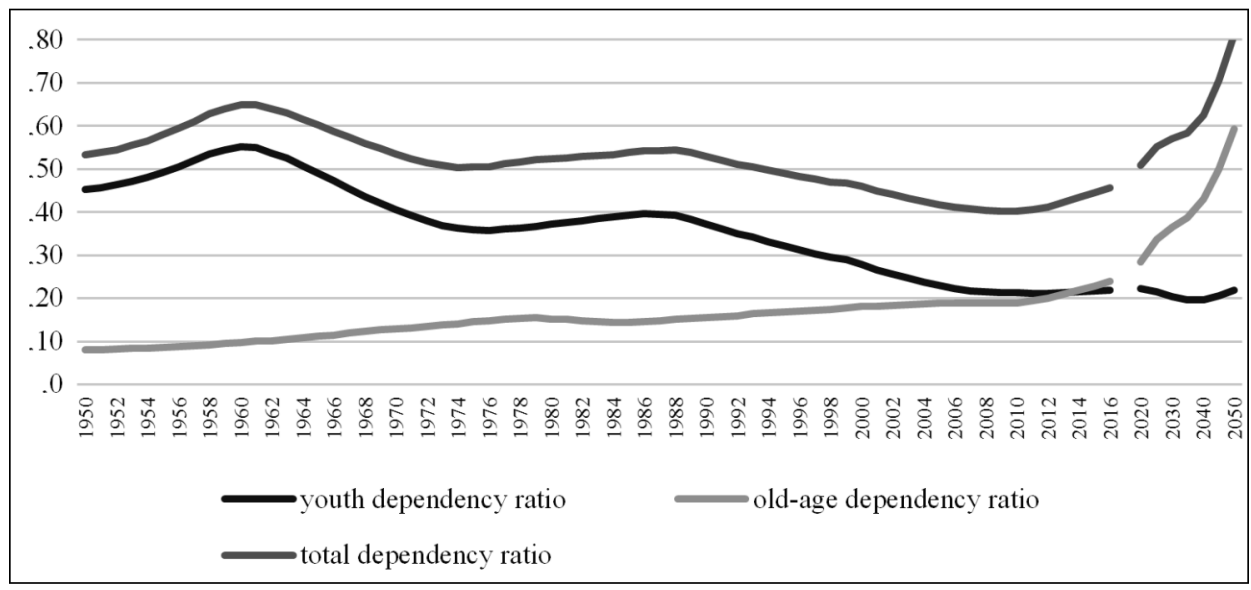

Source: see chart 1 .

In 2016 the youth dependency ratio amounted to 0.219 , i.e. there were 219 persons of a pre-productive age per 1000 people aged 15-64 (chart 5). The sum of the percentage of young persons (0-14) and old persons (65 and over) create the youth dependency ratio. In 2016 the ratio amounted to 0.458 , i.e. 458 people in either the pre-productive age group or the post-productive age in relation to 1000 people of a productive age. It is predicted that the youth dependency ratio will increase almost two times - from 0.458 in 2016 to 0.812 in 2050.

\section{The analysis of changes in the old age level of Polish society on the basis of the median age and average life expectancy}

The assessment of the advancement of changes in the ageing level of the society in the dynamic perspective uses the age median, i.e. the middle age setting the age limit that was reached by half of the population, while it was not reached by the second half. The value of the median from the range of $30-$ 34 years old means an old population in demographic terms, whereas when it is higher than 35 years old it is very old in demographic terms. In accordance with this classification Poland entered the stage of demographic old age in the 1980s, at the end of the 1990s into the stage when the society is very old in demographic terms. In the years 1950-2016 there was more than a 1.58-fold increase of the age median for men and 1.55-fold increase of the age median for women (chart 6). A considerable increase of the medium age has been recorded within the last 25 years. In 1990 the age median of men amounted to 30.9 years, in the case of women it amounted to 33.7 years. In 2016 the value of this measure in the case 
CHART 6

Age median of Polish population for selected years of the period 1950-2016 and for forecasted years 2020, 2035 and 2050

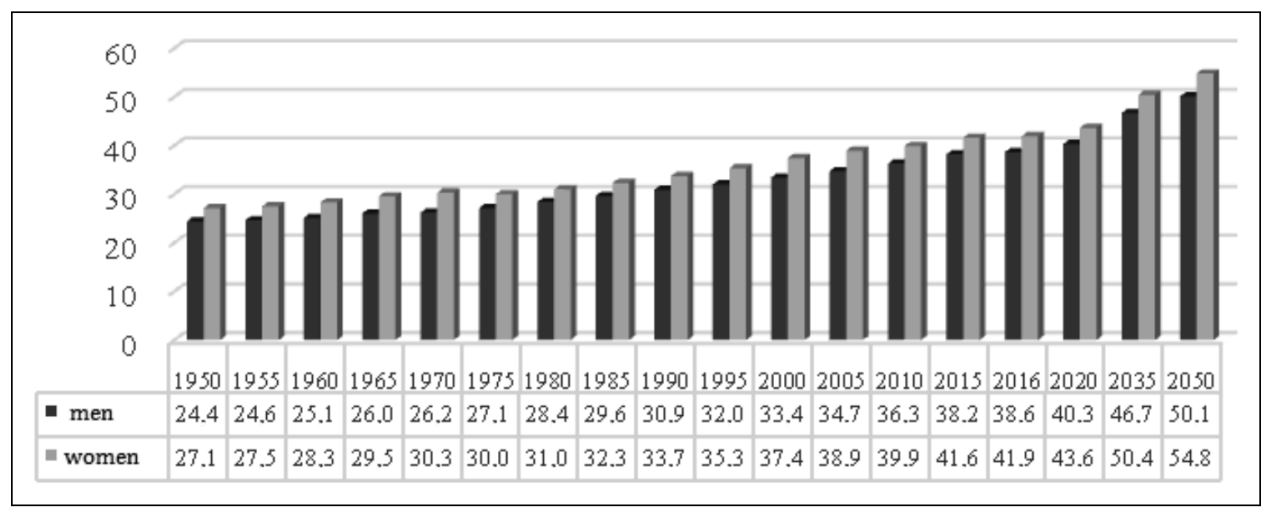

Source: see chart 1.

CHART 7

Average life expectancy in Poland in the years 1950-2016

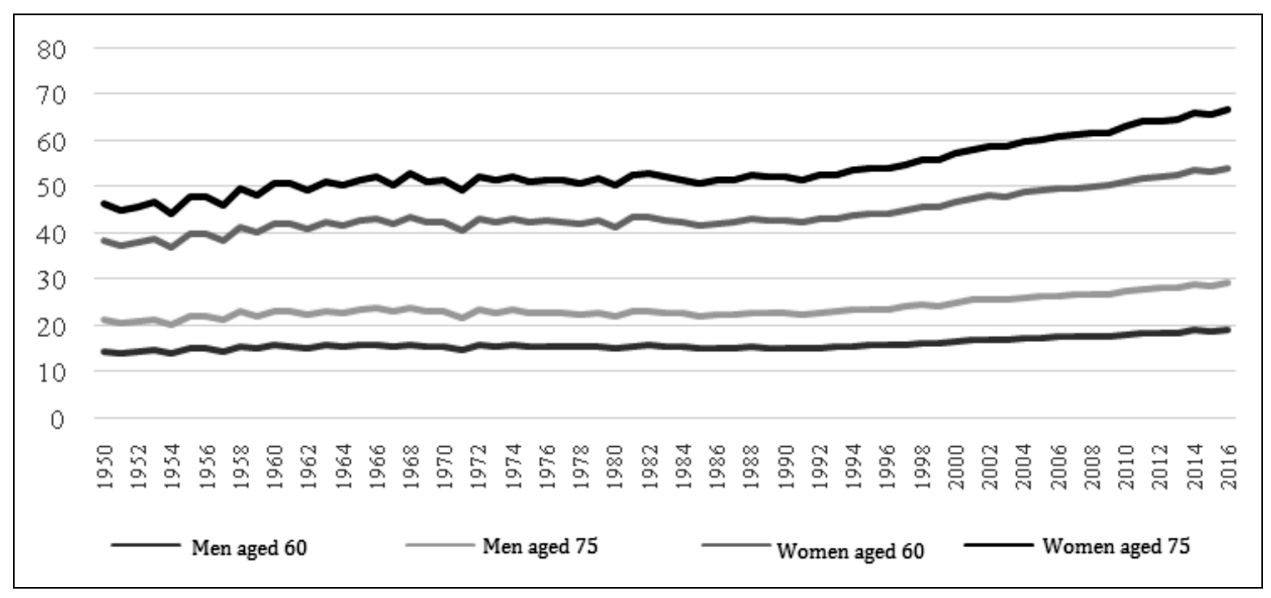

Source: [https://stat.gov.pl/obszary-tematyczne/ludnosc/trwanie-zycia/trwanie-zycia-tablice,1, 1.html, date of entry 10.01.2018].

of men amounted to 38.6 years and was 3.3 years lower than the age median of women. There is an anticipated further increase of the middle age in 2020 for men to 40.3 years, for women - 43.6 years, whereas in 2050 for men to 50.1 years, for women -54.8 years.

In the years 1950-2016 there was observed a prolonging of the further existence of people aged 60 and 75 (chart 7). Dynamic increase of average life 
duration in Poland may be observed from 1990. In 1950 a 60-year old man still had 14.6 years to live, whereas a woman in the same age -17.1; on average however, in 2016 a man could live 19.3 years, and woman - 24.5 years. Therefore, further life duration of a 60-year old person was longer in comparison with the year 1950 by 4.7 years for men and 7.4 years for women. Women reaching the age of 60 have at least 5 years more, whereas at the age of 75 years old 2.5 years more of further life duration than men. The difference is the result of the too early death rate of men observed in all the age groups of poulation, including the younger ones.

\section{Conclusions}

The elaboration presents detailed analysis of the degree of advancement and the dynamics of changes in the ageing process of Poland's population. The usage of various statistical measures for the analysis of the ageing process confirms the systematic process of the ageing of Poland's population. The elaboration presents a synthetic analysis of the transformations in the age structure of Poland's population with division into three age groups: 0-14 years old, 1564 years old, 65 years old and over. In the years 1950-2016 there were observed transformations in the structure of population in accordance with the biological age characterized by varied tendency and intensification depending on age groups, an increase in the value of the median age, and the average life duration of the population. It was shown that changes in the relation between particular age groups translate into the value of the old age index and the value of the coefficient of demographic burden.

The reflections regarding changes in the structure of Poland population by age in the years 1950-2016 enable drawing the following conclusions:

1) there were observed changes of varied intensity in population percentages in particular age groups: 0-14 years old, 15-64 years old, 65 years old and more;

2) there was recorded a stable decreasing trend as regards the participation of persons aged $0-14$ years old in the population in general, relatively stable participation of persons in the age group 15-64 years old and a stable upward trend as regards the participation of persons from the age group 65 years old and over;

3) there was observed diversification in the similarity of age structures in the population in the dynamic perspective;

4) there was recorded an increasing trend in terms of the value of the old age coefficient and the coefficient of old age dependency ratio by persons of a post-productive age;

5) there was observed a stable increasing trend of middle age, but the rate of becoming old was diversified in terms of sex. 
The obtained results confirm the analyses of GUS which imply that "Poland is in such a moment of demographic development that even the increase of birth coefficient to a level that guarantees simple generational replacement in a short period will not cause reversal of these processes and will not stop the reduction of the country's population. In a situation of such considerable deformation of the population structure the process of demographic reconstruction is a slow process which requires consistent, long-lasting activities" [Prognoza ludności na lata 2014-2050, p. 109]. While analyzing the situation of Poland in comparison with other countries of the European Union one ought to observe that until recently Poland had been perceived in Europe as a "young" country. However, presently the dynamics of population ageing is clearly larger than the average dynamics in the entire EU. Poland is already in the stage of demographic old age, while the forecasts prepared by GUS indicate that in 2025 Poland will enter the stage of hyper old age. According to the forecasts for the years 2020-2050 Poland is likely to become the country where the increase in persons of senior age will take place at the fastest rate among all the countries of the European Union [more: Sytuacja demograficzna Polski na tle Europy], which means that Polish society will be one of the societies that are becoming old at the most rapid rate in the entire EU. There are also forecasts regarding both the reduction in the population of Poland and change in the participation of particular age groups in the entire population. The old age dependency ratio predicted for Poland for 2030 at the level of 0.570 means that among 1000 people of a productive age (15-64) there will be as many as 570 people of a non-productive age (0-14 years old or aged 65 and over). Thus, one person of a non-productive age will be maintained by fewer than two persons of a productive age. Simultaneously, in accordance with demographic forecasts, in 2030 an average Polish man will live 77.6 years, whereas a Polish woman - 83.3. In 2060 the average life expectancy of men will be 82 years, whereas in the case of women -88 years.

The ageing of Polish society is a difficult socio-economic problem that has considerable influence on the labor market and on public finances. In the light of the conducted analyses more importance is attached to the concept of the socalled senior age economy (also termed as silver economy) treated in a wider perspective as the economic system directed at using the potential of elderly persons and taking their needs into consideration [see Silver Economy in Poland..., 2018]. The silver economy may be understood as "the potential of economic growth resulting from the coexistence of the possibilities of supplying proper goods and services (owing to considerable flexibility of markets, the possibility of conducting research and development work, high education level) and increasing the purchasing power of older consumers" or the "combination of good conditions of supplies (high level of education, research and development, sensitive and flexible markets) with rising purchasing power of older consumers which offers new possibilities of economic growth [European Commission..., 2007, p. 96].

The most important areas of the "silver economy" include the provision of possibly the longest occupational activity and self-reliance of elderly people, 
keeping senior people occupied, concern for their health and image, ensuring social integration for them, providing them with financial services "sensitive in terms of their age" [Szukalski, 2012, p. 8]. It needs emphasizing that along with the population ageing there arises a considerable niche - the marketing of goods and services addressed to elderly people - that needs to be managed.

The presented analysis of the process of Poland's ageing population may constitute the initial resource of knowledge for formulating general comments and development directions for the silver economy in the sphere of "the conditions of satisfying the needs of old people and shaping proper relations between older generation and younger generations, by means of reducing the dependence of older people on younger ones and by shaping the relations of intergenerational solidarity" [Szatur-Jaworska, 2000, p. 121]. However, one needs to remember that more detailed analysis ought to take into consideration the fact that the intensification of the ageing process of Polish society is diversified in spatial terms. In accordance with GUS forecasts, some areas are threatened by depopulation, whereas others are subject to stagnation or a relatively small decrease of population. Indepth analysis is required for the changes in the age structure of elderly people, i.e. aged 65 and over. The population of elderly people may be divided, among others, into categories that reflect the degree of professional or social activity of those people that reflects the range of needs represented by them (e.g. classification of persons aged 60 and over as younger (60-69 lat), older (70-79) and old (80 years and over)).

\section{References}

Abramowska-Kmon A., 2011, O nowych miarach zaawansowania procesu starzenia się ludności, "Studia Demograficzne", No. 1(159).

Baranowska A., 2013, Starzenie się społeczeństwa i związane z tym konsekwencje - perspektywa socjologiczna, [w:] Społeczny wymiar życia i aktywności osób starszych, Baranowska A., Kościńska E., Wasilewska-Ostrowska K.M. (red.), Wydawnictwo Edukacyjne Akapit, Torun.

Chomątowski S., Sokołowski A., 1978, Taksonomia struktur, "Przegląd Statystyczny", No. 2.

Clarke J.I., 1965, Population Geography, Pergamon Press, Oxford.

European Commission, Europe's demographic future. Facts and figures on challenges and opportunities, Luxembourg 2007.

Cieślak M., 2004, Pomiar procesu starzenia się ludności, "Studia Demograficzne", No. 2 (146).

d'Albis H., Collard F., 2013, Age Groups and the Measure of Population Aging, “Demographic Research", No. 29.

Długosz Z., 1998, Próba określenia zmian starości demograficznej Polski w ujęciu przestrzennym, "Wiadomości Statystyczne", No. 3. 
Frątczak E., 2002, Proces starzenia się ludności Polski, "Studia Demograficzne", No. 2(142).

Holzer J., 2003, Demografia, Polskie Wydawnictwo Ekonomiczne, Warszawa. http://stat.gov.pl/obszary-tematyczne/ludnosc/prognoza-ludnosci/prognozaludnosci-na-lata-2014-2050-opracowana-2014-r-,1,5.html [date of entry 10.01.2018]

http://stat.gov.pl/obszary-tematyczne/roczniki-statystyczne/roczniki-statysty

czne/rocznik-demograficzny-2017,3,11.html [date of entry 10.01.2018]

http://stat.gov.pl/obszary-tematyczne/ludnosc/ludnosc/struktura-ludnosci,

16,1.html [date of entry: 10.01.2018]

http://www.stat.gov.pl/gus/definicje_PLK_HTML.htm?id=POJ-1718.htm [date of entry: 10.01.2018]

https://stat.gov.pl/obszary-tematyczne/ludnosc/trwanie-zycia/trwanie-zyciatablice,1,1.html [date of entry 10.01.2018]

Jurek Ł., 2012, Ekonomia starzejącego się społeczeństwa. Wydawnictwo Difin SA, Warszawa.

Kondrat W., 1972, Zmiany w strukturze ludności według płci i wieku w latach 1950, 1960, 1970, "Studia i Prace Statystyczne", No. 40.

Kot S.M., Kurkiewicz J., 2004, The New Measures of the Population Ageing, "Studia Demograficzne", No. 2 (146).

Kosiński L., 1967, Geografia ludności, PWN, Warszawa.

Kowaleski J.T. (red.), 2006, Ludzie starzy w polskim społeczeństwie w pierwszych dekadach XXI wieku, Wydawnictwo Uniwersytetu Łódzkiego, Łódź.

Kowaleski J.T., 2011, Przestrzenne zróżnicowanie starzenia się ludności Polski. Przyczyny - etapy - następstwa, Wydawnictwo UŁ, Łódź.

Kowaleski J.T., Szukalski P. (red.), 2004, Nasze starzejące się społeczeństwo. Nadzieje i zagrożenia, Wydawnictwo Uniwersytetu Łódzkiego, Łódź.

Kowaleski J.T., Szukalski P. (red.), 2006, Starość i starzenie się jako doświadczenie jednostek i zbiorowości ludzkich, Wydawnictwo Uniwersytetu Łódzkiego, Łódź.

Kurek S., 2004, The Spatial Distribution of Population Ageing in Poland in the Years 1988-2001, "Bulletin of Geography", No. 2.

Kurek S., 2008, Typologia starzenia się ludności Polski w ujęciu przestrzennym, Prace Monograficzne AP, No. 497, Kraków.

Kurkiewicz J. (red.), 2010, Procesy demograficzne i metody ich analizy, Wydawnictwo Uniwersytetu Ekonomicznego w Krakowie, Kraków.

Młodak A., 2006, Analiza taksonomiczna w statystyce regionalnej, Difin, Warsaw.

Perspektywy demograficzne jako wyzwanie dla polityki ludności, electronic document, access mode: [http://bip.stat.gov.pl/organizacja-statystyki-publicznej/rza dowa-rada-ludnosciowa/publikacje-rzadowej-rady-ludnosciowej/, date of entry: 10.01.2018].

Pociecha J., Podolec B., Sokołowski A., Zając K., 1988, Metody taksonomiczne w badaniach społeczno-ekonomicznych, PWN, Warszawa. 
Podogrodzka M., 2014, Przestrzenne zróżnicowanie ludności według wieku w Polsce w 1991-2010, "Studia Ekonomiczne. Zeszyty Naukowe Uniwersytetu Ekonomicznego w Katowicach", No. 167.

Podogrodzka M., 2016a, Starzenie się ludności Polski w przekroju regionalnym, "Studia Ekonomiczne. Zeszyty Naukowe Uniwersytetu Ekonomicznego w Katowicach", No. 290.

Podogrodzka M., 2016b, Przestrzenna konwergencja indeksu starości w Polsce, "Acta Universitatis Lodziensis Folia Oeconomica" No. 4 (324).

Podstawowe informacje o rozwoju demograficznym Polski do 2014 roku. Raport GUS, electronic document, access mode: [https://stat.gov.pl/files/gfx/portalin formacyjny/pl/defaultaktualnosci/5468/12/5/1/podstawowe_informacje_ o_rozwoju_demograficznym_polski_do_2014.pdf, date of entry: 10.01.2018].

Potrykowska A., 2003, Przestrzenne zróżnicowanie procesu starzenia się ludności i migracji osób w starszym wieku w Polsce, "Przegląd Geograficzny", No. 1.

Prognoza ludności na lata 2014-2050 GUS, electronic document, access mode: [http://stat.gov.pl/obszary-tematyczne/ludnosc/prognoza-ludnosci/prog noza-ludnosci-na-lata-2014-2050-opracowana-2014-r-,1,5.html, date of entry 10.01.2018].

Rączaszek A., Koczur W. (red.), 2014, Polityka społeczna wobec przemian demograficznych, "Studia Ekonomiczne Zeszyty Naukowe Wydziałowe Uniwersytetu Ekonomicznego w Katowicach", Katowice.

Rosset E., 1967, Ludzie starzy. Studium demograficzne, PWE, Warszawa.

Rosset E., 1959, Proces starzenia się ludności. Studium demograficzne, PWG, Warsaw.

Rowland D.T., 1996, Population Momentum as a Measure of Aging, "European Journal of Population", No. 12.

Sanderson W., Scherbov S., 2005, Average Remaining Lifetimes Can Increase as Human Populations Age, "Nature", No. 435.

Silver Economy in Poland - State and Measurement Methods, Research studies, Final methodological report, 2018, Statistics Poland, Warsaw, electronic document, access mode: [http://stat.gov.pl/statystyka-regionalna/statystykadla-polityki-spojnosci/statystyka-dla-polityki-spojnosci-2016-2018/badania /ekonomia/, date of entry: 11.11.2018].

Stańczak J., Dorota Szałtys D., 2017, Regionalne zróżnicowanie procesu starzenia się ludności Polski w latach 1990-2015 oraz w perspektywie do 2040 roku, electronic document, access mode: https://stat.gov.pl/obszary-tematyczne/ludnosc/ ludnosc/regionalne-zroznicowanie-procesu-starzenia-sie-ludnosci-polskiw-latach-1990-2015-oraz-w-perspektywie-do-2040-r-,28,1.html, date of entry: 10.01.2018].

Sytuacja demograficzna Polski na tle Europy, electronic document, access mode: [https://stat.gov.pl/obszary-tematyczne/ludnosc/ludnosc/sytuacja-demo graficzna-polski-na-tle-europy,27,1.html, date of entry: 10.01.2018].

Szatur-Jaworska B., 2016, Polityka społeczna - wobec starzenia się ludności - propozycja konceptualizacji pojęcia, "Studia Oeconomica Posnaniensia", Vol. 4. 
Szukalski P., 2012, Trzy kolory: srebrny. Co to takiego silver economy?, "Polityka Społeczna", No. 5-6, Warsaw.

Wasilewska E., 2017, Starość demograficzna obszarów wiejskich i jej zróżnicowanie, "Roczniki Naukowe Ekonomii Rolnictwa i Rozwoju Obszarów Wiejskich", Vol. 104, b. 3.

Wasilewska E., 2014, Przemiany w strukturze aktywności ekonomicznej osób w wie$k u$ 50+ w Polsce, "Zeszyty Naukowe Szkoły Głównej Gospodarstwa Wiejskiego Ekonomika i Organizacja Gospodarki Żywnościowej", No. 105.

Wasilewska-Ostrowska K., 2013, Samotność osób starszych w kontekście zmian demograficznych, "Kultura i Edukacja", No. 4 (97).

Wieniecki I.G., 1981, Metody statystyczne w demografii, PWE, Warszawa.

Wolańska W., 2013, Przestrzenne zróżnicowanie starzenia się ludności Polski w latach 1995-2035, "Acta Universitatis Lodziensis Folia Oconomica", No. 291.

Zimnoch K., 2013, Starzenie się i srebrna gospodarka w uwarunkowaniach rozwojowych Podlasia, "Optimum. Studia Ekonomiczne", No. 4 (64). 